\title{
ATR-FTIR FOR DISCRIMINATION OF ESPRESSO AND AMERICANO COFFEE PODS
}

\author{
Andrés Felipe Bahamon Monjeㄹ, Lina Ximena Parrado², Nelson Gutiérrez-Guzmán ${ }^{3}$
}

(Received: July 31, 2018; accepted: September 28, 2018)

\begin{abstract}
Roasted and ground coffee for encapsulation in single-serve capsules compatible with keurig® and coffee powder obtained from Nespresso $\mathbb{R}$ commercial capsules were analyzed for $\mathrm{pH}$ value, titratable acidity, moisture content, water activity and color (lightness); a data matrix that contains the physicochemical properties and the absorbance measurements using a baseline of 1600 to $1800 \mathrm{~cm}-1$ by FTIR-ATR technique, was evaluated through the combined methods of principal component analysis (PCA) and cluster analysis in order to discriminate between the types of capsules. In the PCA biplot two distinct groups can be identified and in the cluster analysis two groups are that correspond to the two types of capsules. The results reveal that FTIR-ATR based methods seem to be a promising alternative for the discrimination of coffee samples for the pods industry or for the type of consumption.
\end{abstract}

Index terms: Coffee brewing Single-serve brewer, Coffee pods, Extraction brew physiochemical properties, FTIR spectra.

\section{ATR-FTIR PARA DISCRIMINAÇÃO DE CÁPSULAS DE CAFÉ ESPRESSO E AMERICANO}

RESUMO: Café torrado e moído encapsulado para consumo individual compatível com keurig® e pó de café obtido cápsulas comerciais $\mathrm{Nespresso}{ }^{\circledR}$, foram analisadas para valores de $\mathrm{pH}$, acidez titulável, teor de água, atividade de água e cor (luminosidade); uma matriz de dados com as propriedades físico-químicas e medições de absorbância usando uma linha de base de 1600 a $1800 \mathrm{~cm}-1$ pela técnica ATR-FTIR, foi avaliada por meio de métodos combinados de análise de componentes principais (PCA) e análise de clusters a fim de discriminar entre os tipos de cápsulas. No gráfico do PCA podem ser identificados dois grupos distintos, e na análise de clusters, dois grupos que correspondem a dois tipos de cápsulas. Os resultados mostraram que métodos baseados em ATR-FTIR podem ser uma alternativa promissora para a discriminação de amostras de café na indústria de cápsulas ou para o tipo de consumo.

Termos para indexação: Máquina de café em dose única, Cápsulas de café, Propriedades físico-químicas no extrato de café, Espectro de FTIR.

\section{INTRODUCTION}

Espresso and americano coffee are a widely consumed beverages worldwide; while the espresso coffee has been defined as a beverage prepared by submitting ground roasted coffee beans to hot water at a certain pressure for a short time, the americano coffee is defined how a diluted espresso, extracted with higher water volume; after the extraction, an americano coffee has a similar volume to a filtered coffee.

Traditionally, the espresso and americano coffees were extracted in a same big and expensive coffee machines, recently new devices was development to make this beverages based on pods systems, they have gained market share because they are user-friendly and they also make it easy to prepare good-quality coffees through the reduction of uncontrolled preparation variables (PARENTI et al., 2013); although encapsulated coffee is increasingly popular, little research information exists about this product. WANG et al. (2016) evaluated the effects of the capsule parameters on extraction yield and physiochemical properties of coffee brews prepared using a commercial single serve brewer Keurig ${ }^{\circledR}$; DESBROW et al. (2017) quantified the caffeine content of the Nespresso ${ }^{\circledR}$ coffee pod and BELCHIOR et al. (2017) evaluated the potential of ATR-FTIR and chemometrics to discriminate espresso coffees with different sensory characteristics described by a panel of coffee tasters.

Some food analysis techniques are complicated instruments and require time and more costs; FTIR- ATR spectroscopy is a simple technique that requires no sample pretreatment, is fast and provides an overall infrared fingerprint of the specimen; FTIR- ATR have been recently employed for coffee analysis (REIS et al., 2013a); FTIR analysis was used to detect multiple adulterants in roasted and ground coffee CRAIG et al. (2014); to discriminate between defective and non-defective coffee beans prior to roasting (CRAIG et al., 2012) and to evaluate the chlorogenic acid isomer profile and antioxidant capacity of coffee beans (LIANG et al. 2016b).

Since Chlorogenic acids (CGAs) are a major acid group present in Coffee (FARAH \&

${ }^{1,2,3}$ Centro Surcolombiano de Investigación en Café CESURCAFE/Universidad Surcolombiana - Departamento de Ingeniería Agrícola Cx.P.410001 - Neiva - Colombia - u2010297360@usco.edu.co,u20142131808@usco.edu.co,ngutierrezg@usco.edu.co 
DONANGELO, 2006), and caffeine content is relevant in coffee analysis, authors have proposed for the identification and quantification of caffeine and CGAs using infrared spectra finding that peaks are usually located within the wavelength range from $1600 \mathrm{~cm}-1$ to $1800 \mathrm{~cm}-1$ (Table 1).

The objective in this work was to investigate the feasibility of using some physicochemical properties and the bands of the FTIR-ATR spectrum where the CGA's and Caffeine peaks are highlighted (1600-1800 cm-1), in conjunction with PCA and HCA to discriminate between americano and espresso coffee pods.

\section{MATERIALS AND METHODS}

\subsection{Samples}

Six commercial Nespresso ${ }^{\circledR}$ coffee pods (7g coffee net weight) (EC) and twelve americano coffee pods (12g coffee net weight) (AC) of which three commercial Keurig® k-cup coffee pods and nine roasted and grinding coffee samples packed in the single-serve coffee capsule EZ-CUP'.0 compatible with keurig K-cup brewers were used in the analysis; the single origin coffee and encapsulated process is presented in the table 2 . The manually encapsulated and sealed process occurred in a laboratory prototype of coffee pod packaging with a single chamber (Figure 1).

\subsection{Physicochemical analysis in coffee powder Moisture content}

Before being packed, the roasted and ground coffee for the Keurig ${ }^{\circledR}$ pods and the coffee powder inside of the Nespresso ${ }^{\circledR}$ pods (Factory packed) were evaluated for moisture content with MB45 OHAUS infrared moisture analyzer.

\section{Water activity measurement}

$3 \pm 1 \mathrm{~g}$ of coffee powder were placed in the sample chamber of a vapor sorption analyzer, at 25oC. (VSA Aqualab Decagon Device, Inc. Pullman, WA).

TABLE 1 - Reported bibliography of infrared spectral analysis in coffee.

\begin{tabular}{|c|c|c|}
\hline Molecules & Wavelength $(\mathrm{W})$ - peaks $(\mathrm{P})$ & Author(s)/year \\
\hline \multirow{14}{*}{ Caffeine } & $\mathrm{W}(1660-1600) \mathrm{cm}^{-1}$ & (KEMSLEY et al, 1995) \\
\hline & $\mathrm{P}(1700,1658,1600) \mathrm{cm}^{-1}$ & (DAGHBOUCHE et al, 1997) \\
\hline & $\mathrm{P}(1659,1554,1710) \mathrm{cm}^{-1}$ & (BOUHSAIN et al, 1999) \\
\hline & $\mathrm{W}(4000-800) \mathrm{cm}^{-1}, \mathrm{P}(1700,1659) \mathrm{cm}^{-1}$ & (GARRIGUES et al, 2000) \\
\hline & $\mathrm{W}(1800-1300) \mathrm{cm}^{-1}$ & (NAJAFI et al, 2003) \\
\hline & $\mathrm{P}(2924,1591,1659,1585) \mathrm{cm}^{-1}$ & (ESTEBAN-DÍEZ et al, 2004) \\
\hline & $\mathrm{P}(1659,1705) \mathrm{cm}^{-1}$ & (GALLIGNANI et al, 2008) \\
\hline & $\mathrm{P}(1650,1600) \mathrm{cm}^{-1}$ & (WANG \& LIM, 2012) \\
\hline & $\mathrm{P}(1650,1745) \mathrm{cm}^{-1}$ & (RIVERA et al, 2013) \\
\hline & $\mathrm{P}(2923,2854,2925,2848,1659,1655) \mathrm{cm}^{-1}$ & (REIS et al, 2013b) \\
\hline & $\mathrm{P}(1659) \mathrm{cm}^{-1}$ & (BARBIN et al, 2014) \\
\hline & $\mathrm{W}(1700-1600) \mathrm{cm}^{-1}, \mathrm{P}(1642) \mathrm{cm}^{-1}$ & (ABDALLA et al, 2015) \\
\hline & $\mathrm{P}(1625) \mathrm{cm}^{-1}$ & (CRAIG et al, 2018) \\
\hline & $\mathrm{P}(1655,1591,1072) \mathrm{cm}^{-1}$ & (BELCHIOR et al, 2017) \\
\hline \multirow{7}{*}{ CGAs } & $\mathrm{W}(1450-1000) \mathrm{cm}^{-1}, \mathrm{P}(1300,1150) \mathrm{cm}^{-1}$ & $\begin{array}{l}\text { (KEMSLEY et al, 1995), (BRIANDET et } \\
\text { al, 1996), (REIS et al, 2013b) }\end{array}$ \\
\hline & $\mathrm{P}(1375,1074)$ & (BUFFO \& CARDELLI-FREIRE, 2004) \\
\hline & $\mathrm{P}(1160,1250,1380) \mathrm{cm}^{-1}$ & (RIVERA et al, 2013) \\
\hline & $\mathrm{P}(1868,1741) \mathrm{cm}^{-1}$ & (BARBIN et al, 2014) \\
\hline & $\mathrm{P}(1605,1627,1680,1742) \mathrm{cm}^{-1}$ & (LIANG et al, 2016a) \\
\hline & $\mathrm{P}(809,1032,1120,1165) \mathrm{cm}^{-1}$ & (LIANG et al, 2016b) \\
\hline & $\mathrm{W}(1375-1074) \mathrm{cm}^{-1}, \mathrm{P}(1072) \mathrm{cm}^{-1}$ & (BELCHIOR et al, 2017) \\
\hline
\end{tabular}


TABLE 2 - Samples, origin and packed process.

\begin{tabular}{lll}
\hline Type of capsule & Origin & Encapsulated \\
\hline AC & Colombia & Manually packed \\
AC & Colombia & Manually packed \\
AC & Bolivia & Manually packed- \\
AC & Guatemala & Manually packed- $^{-}$ \\
AC & Ethiopia & Manually packed- \\
AC & Colombia & Factory packed \\
AC & Colombia & Factory packed \\
AC & Colombia & Factory packed \\
AC & Colombia (Huila) & Manually packed- \\
AC & Colombia (Huila) & Manually packed- \\
AC & Colombia (Huila) & Manually packed- \\
AC & Colombia (Huila) & Factory packed \\
EC & Colombia & Factory packed \\
EC & Colombia & Factory packed \\
EC & Colombia & Factory packed \\
EC & Colombia (Medellin) & Factory packed \\
EC & Colombia & Factory packed \\
EC & Colombia & Factory packed \\
\hline
\end{tabular}

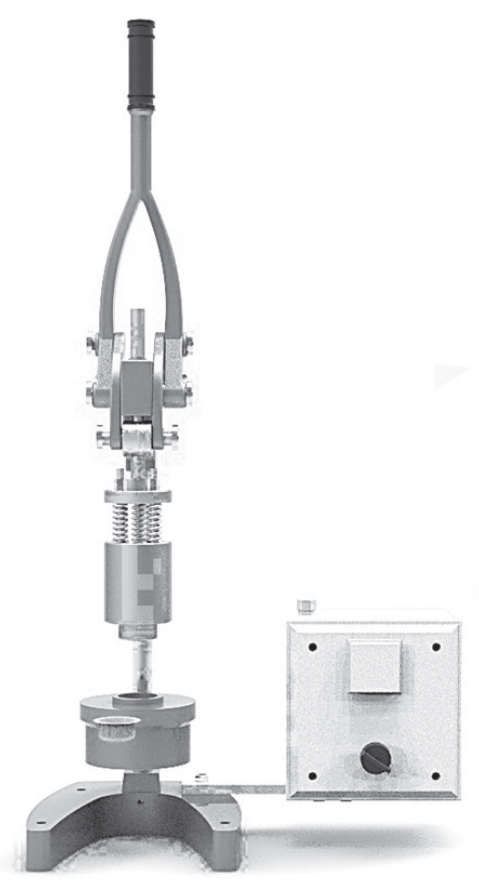

FIGURE 1- Laboratory prototype of coffee pod packaging with a single chamber. 
Color. CIE L*a*b* coordinates were obtained in the coffee powder directly in the $50 \mathrm{~mm}$ (diameter) cell, in triplicate with Minolta CR-410 Colorimeter (Konica Minolta Sensing Inc., Osaka, Japan).

Titratable acidity. Determined by titration, with the Ph meter (BP-3001 manufactured by Trans Instruments, Singapore), $50 \mathrm{ml}$ of distilled water at $90 \pm 2{ }^{\circ} \mathrm{C}$ is filtered with 5 grams of roasted ground coffee. After that, $50 \mathrm{~mL}$ of the filtered extract, filtered by waterman qualitative filter paper, was titrated against $0.1 \mathrm{~N} \mathrm{NaOH}$ solution to $\mathrm{pH} 6.5$ Measurements were taken in duplicate.

\subsection{FTIR analysis}

A FTIR Spectrophotometer (Cary 630 manufactured by Agilent, EEUU) was used in the ATR-FTIR measurements that were performed in a dry atmosphere and at room temperature (20 $\pm 0.5^{\circ} \mathrm{C}$ ). A horizontal ATR sampling accessory (Diamond ATR) equipped with $\mathrm{ZnSe}$ cell was employed. Approximately ( $1 \mathrm{~g})$ of the roasted and ground coffee was placed in the sampling accessory and pressed; the background material was obtained from readings of the accessory without any sample. All spectra were recorded within a range of $1800-1600 \mathrm{~cm}^{-1}$ where the CGA's and Caffeine peaks are variable importance projection scores (VIP)(BELCHIOR et al., 2017), the resolution used was $4 \mathrm{~cm}^{-1}$ with 20 scans and submitted to background subtraction; all samples were analyzed in triplicate. The chlorogenic acid standard SIGMAALDRICH CAS 327-97-9 purity $\geq 99.0 \%$ and caffeine standard CAS 58-08-2 purity $\geq 99.0 \%$ was used for determination of spectrum patterns, in the same range defined with VIP scores.

\subsection{Coffee brewing}

The packed coffee (AC) was brewed using a commercial single serve brewer (K50 Classic Series manufactured by Keurig ${ }^{\circledR}$, USA), using Lungo method with $177 \mathrm{ml}(6 \mathrm{oz})$ hot water; the Nespresso ${ }^{\circledR}$ pods (EC) were brewed with a commercial single serve (C50-US-CW-NE manufactured by Nespresso ${ }^{\circledR}$, Switzerland) with pressure of 19 bar and $40 \mathrm{ml}(1,35 \mathrm{oz})$ hot water.

\subsection{Coffee beverage characterization}

The $\mathrm{pH}$ value of coffee $\mathrm{AC}$ and $\mathrm{EC}$ beverages was measured with $\mathrm{pH}$-meter BP-3001 (Trans Instruments, Singapore); the Refractive index with digital refractometer PR-201 $\alpha$ (Atago, United States) and the beverage lightness $\left(\mathrm{L}^{*}\right)$, was obtained in the coffee beverages, using a CR-A33e Light Protection Tube with Glass of the digital CR410 (Konica Minolta, japan).

\subsection{Statistical analysis}

All data obtained in this study were analyzed statistically, the results are expressed as the mean \pm standard deviation; differences among average values were estimated. Comparisons between the two groups were made by Student's t test using the statistical package Statgraphics Centurion XVI. Average values were considered significantly different when $P \leq 0.05$. Cluster and PCA analysis was applied to the matrix with the absorbance values of the peaks related to representative functional groups in 1600 to $1800 \mathrm{~cm}^{-1}$ region and physicochemical parameters in coffee powder and beverages.

\section{RESULTS AND DISCUSSION}

\subsection{Coffee powder and beverages characterization}

Table 3 presents the results of Student's $t$ test for the comparison of the coffee powder contained in $\mathrm{EC}$ and $\mathrm{AC}$, with the addition of the comparison of the parameters obtained in the $\mathrm{EC}$ and $\mathrm{AC}$ beverages. The moisture content, $\mathrm{a}_{\mathrm{w}}$ and the degree of roasting in coffee powder from EC presented statistically significant differences $(\mathrm{P}<0.05)$ compared to $\mathrm{AC}$; likewise, in the analysis of the beverages, $\mathrm{pH}$, ${ }^{\circ} \mathrm{Brix}$ and beverage lightness $\left(\mathrm{L}^{*}\right)$ presented statistically significant differences $(\mathrm{P}<0.05)$ in the two types of drinks.

The moisture content and $\mathrm{a}_{\mathrm{w}}$ in $\mathrm{AC}$ is significantly higher than in EC, this result may be influenced by the storage conditions or because the AC package material allowed vapor exchange between the inside of the pods and the surrounding environment; the color of roasting in the coffee powder of EC and AC showed significant differences $(p<0.05)$, the magnitudes of the coordinate L obtained $(23.20 \pm 0.53$ and $24.79 \pm 1.5$ respectively) correspond to the degree of dark roasting according to the classification proposed by FRANCA et al. (2009), although the color in samples are statistically different this result is appropriate the preparation of espressos and americano coffee.

The refractive index in the beverages had higher result in espresso than in americano coffee as shown in Table 3, similar results were obtained by GLOESS et al. (2013) where he determined that espresso coffee has a refractive index closer to $4.0 \%$. 
TABLE 3 - Physico-chemical parameters in EC and AC coffee powder and beverages

\begin{tabular}{llcc}
\hline \multirow{2}{*}{ Type } & \multicolumn{2}{c}{ Type of capsule } & AC \\
\hline & Moisture content $(\%)$ & $2.71 \pm 0.62^{\mathrm{a}}$ & $4.51 \pm 1.52^{\mathrm{b}}$ \\
& Water activity (Aw) & $0.25 \pm 0.11^{\mathrm{a}}$ & $0.38 \pm 0.11^{\mathrm{b}}$ \\
Roasted and ground coffee & Color $\left({ }^{\circ} \mathrm{L}\right)$ & $23.20 \pm 0.53^{\mathrm{a}}$ & $24.79 \pm 1.50^{\mathrm{b}}$ \\
& Titratable acidity & $1.68 \pm 0.40^{\mathrm{a}}$ & $1.85 \pm 0.36^{\mathrm{a}}$ \\
\hline & $(0.1 \mathrm{M} \mathrm{NaOH} / \mathrm{ml})$ & $5.21 \pm 0.13^{\mathrm{a}}$ & $4.92 \pm 0.11^{\mathrm{b}}$ \\
& $(\mathrm{Ph})$ & $3.92 \pm 0.53^{\mathrm{a}}$ & $1.66 \pm 0.45^{\mathrm{b}}$ \\
& Refractive index $\left({ }^{\circ} \mathrm{Brix}\right)$ & $32.04 \pm 2.89^{\mathrm{a}}$ & $29.80 \pm 1.15^{\mathrm{b}}$ \\
\hline
\end{tabular}

$\overline{\mathrm{n}}=3$, mean \pm SD. Different letters, in the same row indicate significant difference $(\mathrm{P}<0.05)$.

The author evaluated these parameters in different machines: a semi-automatic espresso machine, an automatic machine and a Nespresso ${ }^{\circledR}$ brand single-use machine. In the americano coffee, the same author determined that the refractive index was slightly higher than $1.0 \%$; finding for the filtered coffee extract a refractive index of $1.03 \pm 0.01 \%$ and for the French press $1.43 \pm 0.01 \%$, these results are similar to those found for the AC. The $\mathrm{pH}$ in beverages was similar as those obtained by FUJIOKA \& SHIBAMOTO (2008) in seven types of commercial coffees varying between $4.95 \pm 0.01$ and $5.99 \pm 0.01$, this author comments that the $\mathrm{pH}$ in extracted coffee is related to the presence of chlorogenic acids, although WANG \& LIM (2012) comments that high values in the $\mathrm{pH}$ of coffee beverages is presents in dark roasted coffee beans and it is associated with the presence of organic acids (citric and malic acids).

\subsection{FTIR spectral analysis}

Figure 2A shows the CGAs (blue) and Caffeine (red) spectrum patterns; the figure 2B shows the approach of the region between 1600 to $1800 \mathrm{~cm}^{-1}$ in the CGAs standard, three peaks are clearly defined, the carbonyl $(\mathrm{C}=\mathrm{O})$ group at $1685 \mathrm{~cm}^{-1}$, the ethylene $(\mathrm{C}=\mathrm{C})$ group at $1636 \mathrm{~cm}^{-1}$ and the phenyl ring stretch at $1599 \mathrm{~cm}^{-1}$ according to LIANG et al, (2016a); likewise, the figure 1C presents the Caffeine standard enlargement, two peaks are clearly defined, the carbonyl $(\mathrm{C}=\mathrm{O})$ group at $1642 \mathrm{~cm}^{-1}$ and the amines $(\mathrm{C}=\mathrm{N})$ group at $1692 \mathrm{~cm}^{-1}$.
Figure 3 presents the americano coffee pods AC (red) and espresso coffee pods EC (blue) spectrums in the region 1600 to $1800 \mathrm{~cm}^{-1}$. The spectrums obtained in this research are similar with those reported by LIANG, et al. (2016a) in commercial coffee samples; the figure 3 shows the CGAs and caffeine molecules superimposed with the functional groups located in the corresponding Wavenumber, which were taken to obtain the respective absorbance values. These absorbance values were included in the multivariate matrix for PCA and HCA analysis.

\subsection{Cluster Analysis}

Figure 4 shows the dendrogram based on similarity of physical-chemical parameters and absorbance values of the functional groups peaks in 1600-1800 cm-1 region. Two clusters are defined for the AC and EC coffee pods samples. All of the americano coffee pods samples AC are included in the Cluster 1, though it is not possible to find a separation pattern for different origins or between commercial or manual encapsulated type. The cluster 2 includes the six espresso coffee pods samples EC.

\subsection{Exploratory analysis}

The biplot of the PCA on the matrix composed with the absorbance values of the peaks related to representative functional groups in 1600 to $1800 \mathrm{~cm}-1$ region and physicochemical parameters in coffee powder and beverages is shown in figure 5 . 


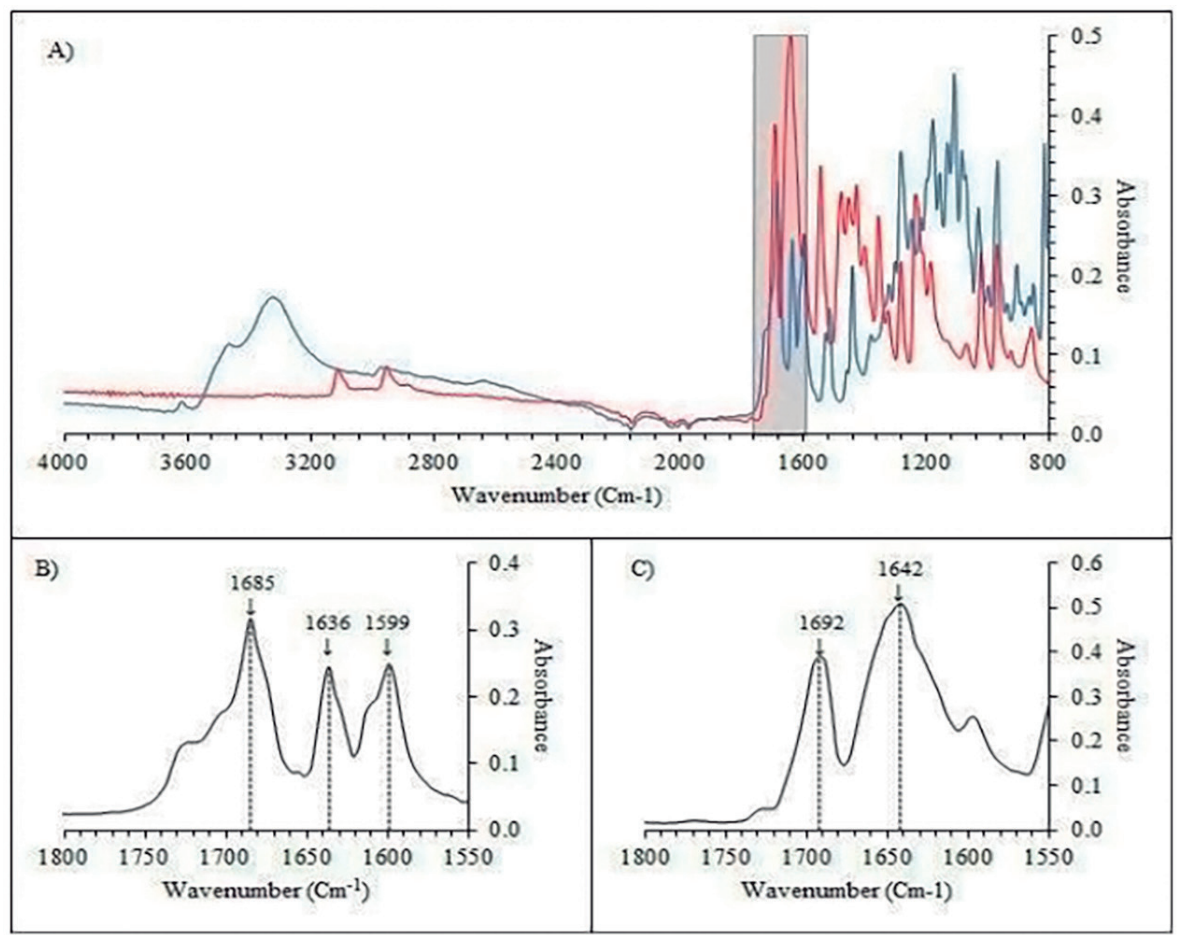

FIGURE 2 - A) FTIR spectral of pure chlorogenic acid and caffeine standards.

B) and C) enlargement of the 1600 to $1800 \mathrm{~cm}^{-1}$ region in CGAs and Caffeine standards

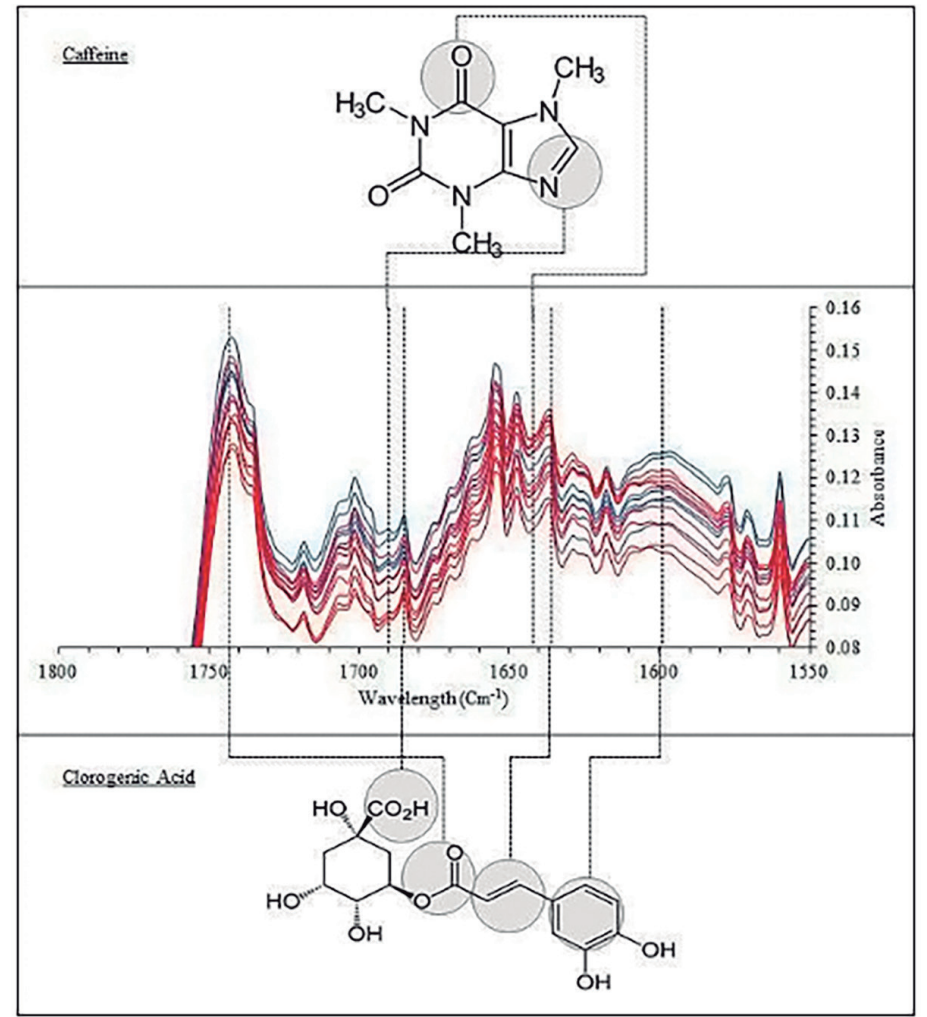

FIGURE 3 - FTIR spectrums for coffee pods AC (red) and EC (blue) samples (CGAs and caffeine molecules superimposed). 


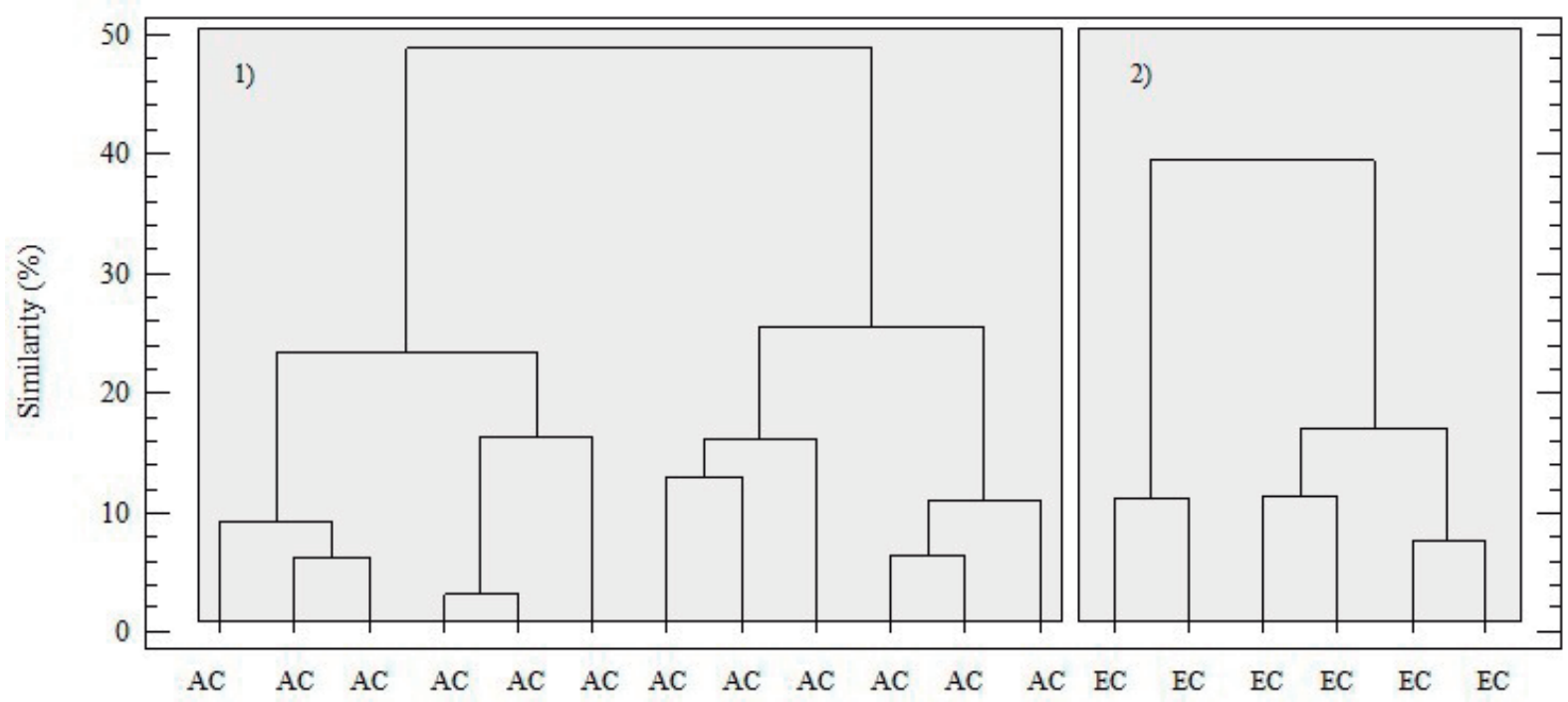

FIGURE 4 - Dendrogram for cluster analysis in americano (AC) and espresso (EC) coffee pods.

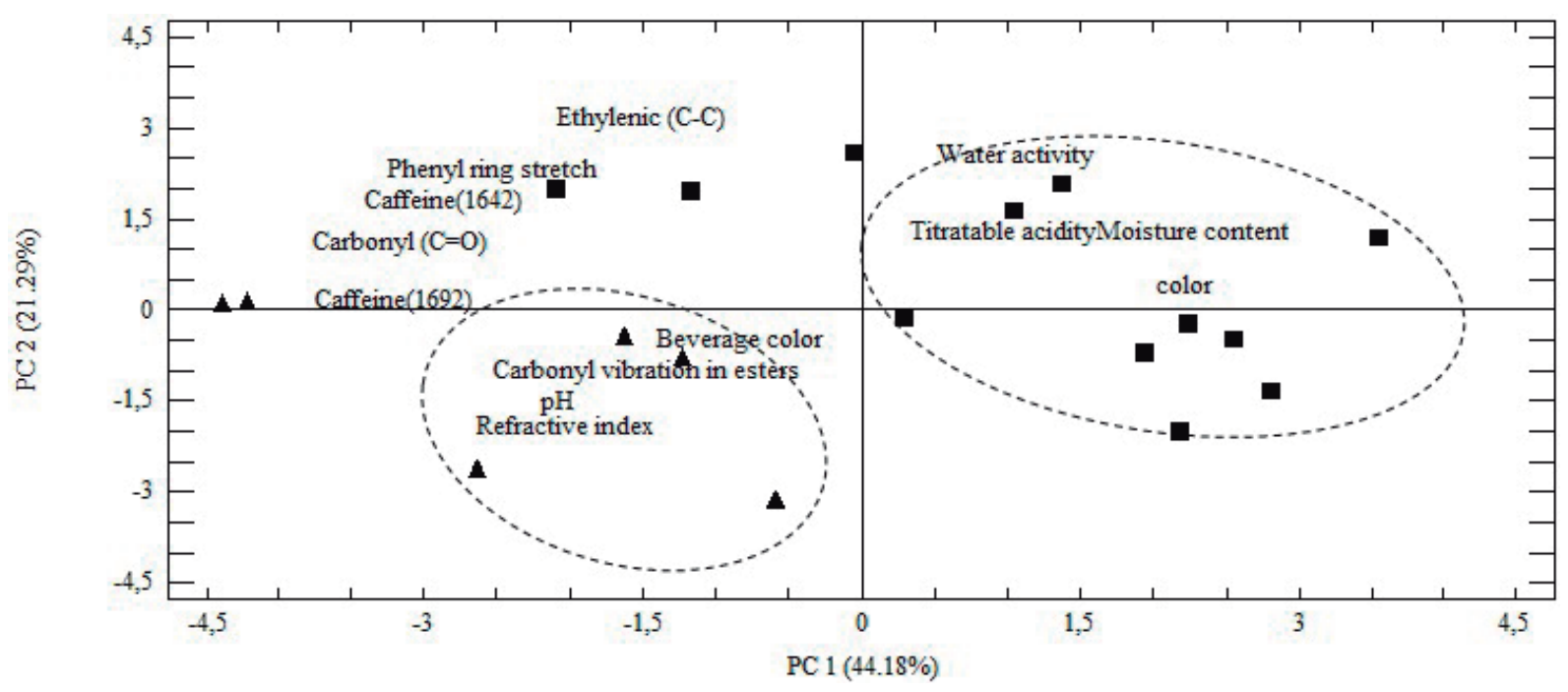

FIGURA 5 - Biplot comparison of espresso coffee pods ( $\mathbf{\Delta})$ and americano coffee pods ( $(\mathbf{\bullet})$.

The first two principal components, PC1 and $\mathrm{PC} 2$, accounted for approximately $65 \%$ of the variability. Two distinct groups can be perceived: AC coffee pod samples are located in positive PC1, while EC coffee pod samples are located in negative PC2 quadrant.

These results reveal that FTIR-based methods seem to be a promising alternative for the discrimination of coffee samples for the pods industry or for the type of consumption; in this study, the FTIR technique allow a discrimination between type of capsules for different extraction methods; so, it could be defined the type of capsules (espresso or americano) can be elaborated according to the type of coffee available.

\section{CONCLUSION}

A high moisture content and $\mathrm{a}_{\mathrm{w}}$ was found in coffee powder AC. This can significantly affect sensory acceptance since high moisture contents can be indicators of product interaction with the environment given the high degree of hygroscopicity of the coffee.

A differentiation was identified between EC and AC coffee pods, PCA and cluster analysis results indicated that coffee samples could be separated into distinct groups, based on both. The absorbance values of the peaks related to representative functional groups in 1600 to 1800 $\mathrm{cm}^{-1}$ region and physicochemical parameters in coffee powder and beverages. 


\section{ACKNOWLEDGMENT}

This work was supported by the South Colombian Coffee Research Center CESURCAFÉ. The authors thank COFFEE ANDES S.A.S for the support in providing some of the coffee samples.

\section{REFERENCES}

ABDALLA, M. A. Determination of caffeine, the active ingredient in different coffee drinks and its characterization by FTIR/ATR and TGA/DTA. International Journal of Engineering and Applied Sciences, Saudi Arabia, v. 2, n. 12, p. 85-89, Dec. 2015.

BARBIN, D. F. et al. Application of infrared spectral techniques on quality and compositional attributes of coffee: An overview. Food Research International, Londrina, v. 61, p. 23-32, July. 2014.

BELCHIOR, V. et al. Attenuated total reflectance fourier transform spectroscopy (atr-ftir) and chemometrics for discrimination of espresso coffees with different sensory characteristics. Food Chemistry, Belo Horizonte, v. 273, p. 178-185, Dec. 2017.

BOUHSAIN, Z. et al. Flow injection fourier transform infrared determination of caffeine in coffee. Vibrational Spectroscopy, Valencia, v. 21, n. 1/2, p. 143-150, Dec. 1999.

BRIANDET, R.; KEMSLEY, E. K.; WILSON, R. H. Approaches to adulteration detection in instant coffees using infrared spectroscopy and chemometrics. Journal of the Science of Food and Agriculture, Norwich, v. 71, n. 3, p. 359-366, July. 1996.

BUFFO, R. A. CARDELLI-FREIRE, C. Coffee flavour: an overview. Flavour and Fragance Journal, Minnesota, v. 19, n. 2, p. 99-104, Feb. 2004.

CRAIG, AP. et al. Mid infrared spectroscopy and chemometrics as tools for the classification of roasted coffees by cup quality. Food Chemistry, Belo Horizonte, v. 245, p. 1052-1061, Apr. 2018.

CRAIG, A. P.; FRANCA, A. S.; OLIVEIRA, L. S. Evaluation of the potential of ftir and chemometrics for separation between defective and non-defective coffees. Food Chemistry, Belo Horizonte, v. 132, n. 3 , p. 1368-1374, Dec. 2012.

CRAIG, A. P. et al. Application of elastic net and infrared spectroscopy in the discrimination between defective and non-defective roasted coffees. Talanta, New York, v. 128, p. 393-400, Oct. 2014.
DAGHBOUCHE, Y. et al. Flow injection Fourier transform infrared determination of caffeine in soft drinks. Analytical Chemistry, v. 69, n. 6, p. 10861091, Mar. 1997.

DESBROW, B.; HALL, S.; IRWIN, C. Caffeine content of nespresso ${ }^{\circledR}$ pod coffee $^{\circledR}$ pod coffee. Journal of Nutrition \& Intermediary Metabolism, Queensland, v. 8, p. 60-121, Jun. 2017.

ESTEBAN-DÍEZ, I.; GONZÁLEZ- SAÍZ, J. M.; PIZARRO, C. Prediction of sensory properties of espresso from roasted coffee samples by near infrared spectroscopy. Analytica Chimica Acta, Logroño, v. 525 , n. 2, p. 171-182, Nov. 2004.

FARAH, A.; DONANGELO, A. M. Phenolic compounds in coffee. Brazilian Journal of Plant Physiology, Rio de Janeiro, v. 18, n. 1, p. 23-36, Jan./ Mar. 2006.

FRANCA, A. S. et al. A preliminary evaluation of the effect of processing temperature on coffee roasting degree assessment. Journal of Food Engineering, Belo Horizonte, v. 92, n. 3, p. 345-352, June. 2009.

FUJIOKA, K.; SHIBAMOTO, T. Chlorogenic acid and caffeine contents in various commercial brewed coffees. Food Chemistry, Berkeley, v. 106, n. 1, p. 217-221, Jan. 2008.

GALLIGNANI, M. et al. Determination of caffeine in coffee by means fourier transform infrared spectrometry. Revista técnica de la facultad de ingeniería Universidad del Zulia, Zulia, v. 31, n. 2, p. 95-109, Aug. 2008.

GARRIGUES, J. M. et al. Fourier transform infrared determination of caffeine in roasted coffee samples. Analytical and Bioanalytical Chemistry, Valencia, v. 366, n. 3, p. 319-322, Sept. 2000.

GLOESS, A. N. et al. Comparision of nine common coffee extraction methods: instrumental and sensory analysis. European Food Research and Technology, Zurich, v. 236, n. 4, p. 607-627, June. 2013.

KEMSLEY, E. K.; RUAULT, S.; WILSON, R. H. Discrimination between coffea arabica and coffea canephora variant robusta beans using infrared spectroscopy. Food Chemistry, Norwich, v. 54, n. 2, p. 321-326, Jan. 1995. 
LIANG, N. et al. Application of attenuated total reflectance-Fourier transformed infrared (ATR-FTIR) spectroscopy to determine chlorogenic acid isomer profile and antioxidant capacity of coffee beans. Journal of Agricultural and Food Chemistry, Vancouver, v. 64, n. 3, p. 681-689, Jan. 2016a.

LIANG, N. et al. Interactions between major chlorogenic acid isomers and chemical changes in coffee brew that affect antioxidant activities. Food Chemistry, Vancouver, v. 213, p. 251-259, June. 2016b.

NAJAFI, M. N.; HAMID, A. S.; AFSHIN, R. K. Determination of caffeine in black tea leaves by fourier transform infrared spectrometry using multiple linear regression. Microchemical Journal, Tehran, v. 75, n. 3, p. 151-158, Dec. 2003.

PARENTI, A. et al. Comparison of espresso coffee brewing techniques. Journal of Food Engineering, Firenze, v. 121, p. 112-117, Aug. 2013.

PIZARRO, C. et al. Use of near-infrared spectroscopy and feature selection techniques for predicting the caffeine content and roasting color in roasted coffees. Journal of Agricultural and Food Chemistry, Logroño, v. 55, n. 18, p. 7477-7488, Aug. 2007.
REIS, N.; FRANCA, A. S.; OLIVEIRA, L. S. Quantitative evaluation of multiple adulterants in roasted coffee by diffuse reflectance infrared fourier transform spectroscopy (DRIFTS) and chemometrics. Talanta, Belo Horizonte, v. 115, p. 563-568, June. 2013b.

REIS, N.; FRANCA, A. S.; OLIVEIRA, L. S. Discrimination between roasted coffee, roasted corn and coffee husks by diffuse reflectance infrared fourier transform spectroscopy. Food Science and Technology, Belo Horizonte, v. 50, n. 2, p. 715-722, Mar. 2013a.

RIVERA W.; VELASCO, X.; RINCÓN, C. A. TGA and FTIR evaluation of composition changes produced by roasting of coffee beans. Revista Colombiana de Física, Popayán, v. 45, n. 3, p. 205-208, Nov. 2013.

WANG, N.; LIM, L. T. Fourier transform infrared and physicochemical analyses of roasted coffee. Journal of Agricultural and Food Chemistry, Guelph, v. 60, n. 21, p. 5446-5453, May. 2012.

WANG, X. et al. Effects of capsule parameters on coffee extraction in single-serve brewer. Food Research International, Guelph, v. 89, p. 797-805, Nov. 2016. 